\title{
La reforma de las cofradías novohispanas en el Consejo de Indias, 1767-1820
}

\author{
David CARBajal LóPez \\ Universidad de Guadalajara-Centro Universitario de Los Lagos, Mexico \\ davidclopez@lagos.udg.mx
}

Recepción: 24 de julio de 2011 / Revisión: 10 de diciembre de 2011

Aceptación: 16 de diciembre de 2011 / Publicación: diciembre de 2012

\section{RESUMEN}

El Consejo de Indias participó activamente en la reforma de las cofradías novohispanas, a través de la revisión de más de un centenar de expedientes particulares entre 1767 y 1820 . Por vía de sus fiscales, el Consejo procuró extender la jurisdicción de la Corona sobre ellas, desplazando a la eclesiástica, y redefiniéndolas como "cuerpos de legos". Mas la reforma contempló también la reducción de los gastos de culto en beneficio de la caridad y, la supresión de toda forma de obligación, retribución o "vanidad profana", en beneficio del desinterés y la voluntariedad propias de las que llamaban también "congregaciones piadosas". Los fiscales procuraban así reforzar su carácter religioso y su papel en la protección de lo sagrado.

Palabras clave: cofradías, hermandades, reformas borbónicas, culto religioso, caridad, piedad, México, siglo XVIII.

\section{The Reform of the Confraternities of New Spain in the Council of the Indies, 1767-1820}

\begin{abstract}
The Council of the Indies participated actively in the reform of the confraternities of New Spain, through the review of more than a hundred specific expedients between 1767 and 1820 . Through its fiscales, the Council tried to extend the Crown's jurisdiction over the religious brotherhoods, displacing the clergy and redefining the institutions as "bodies of laymen". But the reform also contemplated the reduction of expenses associated with worship, for the benefit of charity, and the elimination of all forms of obligation, compensation or "profane vanity", in favour of the disinterstedness and self-will of what they also called "pious congregations". The fiscales sought to reinforce their religious character and their role in protecting the sacred.
\end{abstract}

Key words: Confraternities, Religious Brotherhoods, Bourbon Reforms, Worship, Charity, Piety, Mexico, 18th Century.

Sumario: 1. Introducción. 2. Juntas de legos. 3. Obras de caridad. 4. Congregaciones piadosas. 5. Comentarios finales. 6. Referencias bibliográficas. 


\section{INTRODUCCIÓN ${ }^{1}$}

Las cofradías novohispanas en tiempos del reinado de los Borbones han sido abordadas de manera importante en la historiografía reciente, especialmente en cuanto se refiere a su organización y a su amplia tipología. Gracias a trabajos como los de William B. Taylor y John K. Chance ${ }^{2}$, sabemos que las cofradías de los pueblos de indios no eran necesariamente expresiones de continuidad de tradiciones religiosas o comunitarias prehispánicas, y que podrían ser administradas tanto de manera individual como colectiva, sin que sus cargos estuvieran insertados en un sistema jerárquico. Frecuentemente bajo tutela o inclusive en disputa con los párrocos por la elección de sus autoridades y la administración de sus bienes, estos últimos consistentes por lo común en ganado y tierras, fueron una de las fuentes de tensión más importantes de la vida local en varias regiones ${ }^{3}$.

Las cofradías urbanas de españoles, como las de la Ciudad de México 4 , eran "comunidades de fieles" que gozaban de una importante autonomía, particularmente celosas en la administración de sus bienes y en el culto a las imágenes que les daban identidad. Las había que podían hacer uso de grandes caudales y patrocinar importantes iniciativas en ámbitos como la caridad y la educación, como han mostrado los estudios de las cofradías de "nacionales", en particular las de los vascos ${ }^{5}$, o también de algunas cofradías asociadas a gremios de artesanos. Gracias a esa riqueza, ciertas hermandades otorgaban financiamiento a particulares a través de sus capitales propios o de obras pías, por lo que han sido calificadas de verdaderas "instituciones de crédito bancario" 6 .

Urbanas o rurales, tenían asimismo un papel destacado en las prácticas mortuorias, pagando los entierros y funerales de sus miembros, celebrando por ellos misas y oraciones, distribuyendo incluso limosnas a los deudos, hasta el punto de ser consideradas en algún caso como "sociedades funerarias"7. Desde luego, su función religiosa era fundamental, no sólo en el culto de los santos patronos locales, sino también en la distribución de indulgencias y otras gracias espirituales ${ }^{8}$.

Ahora bien, a más de su papel en la vida religiosa, social y económica novohispanas, los estudios recientes han destacado sobre todo las reformas de las que fueron objeto en las últimas décadas del siglo XVIII. Tal fue su importancia que la historiografía suele describirlas utilizando expresiones particularmente dramáticas. Habrían padecido "intenciones destructoras", "campañas en su contra", "agresiones", "em-

1 Este artículo ha sido posible gracias a una beca de estancias postdoctorales del Consejo Nacional de Ciencia y Tecnología (CONACYT) de México, y durante dicha estancia, al gentil respaldo del Dr. José de Jesús Hernández Palomo de la Escuela de Estudios Hispano-Americanos de Sevilla.

2 TAYLOR - Chance, 1985, pp. 1-26.

3 TAYLOR, 1999, pp. 449-472; TANCK, 2004.

4 Véanse los estudios de Bazarte, 1989; Bazarte - García, 2001; García, 2007.

5 Luque, 1995; Olveda, 1999.

6 Bazarte, 1989, pp. 115-127.

7 GARCíA, 1999, p. 73.

8 BaZARTE - García, 2001, pp. 32-37; LaVRín, 1998, passim. 
bestidas" o directamente "golpes mortales", tros, no menos que de algunos obispos reformadores.

Cabe destacar que en ese aspecto las cofradías no difieren grandemente de las otras corporaciones religiosas novohispanas de la misma época. Una historiografía ya amplia $^{10}$, ha insistido en la idea de una Iglesia puesta en cuestión bajo el reinado de los Borbones. Los ministros de los reinados de Carlos III y Carlos IV habrían tratado de suprimir los privilegios del clero y de las corporaciones religiosas en aras de consolidar el predominio político de la Corona y fortalecer sus finanzas, secularizando en buena medida los fines principales de la Monarquía. David Brading llega a afirmar: "la Iglesia mexicana sufrió un asalto sin precedente iniciado por ministros y funcionarios que se jactaban de sus ideas 'ilustradas', mostraban una creciente envidia a la riqueza del clero y temían su influencia sobre los fieles" ${ }^{11}$.

En el caso particular de las corporaciones que aquí nos interesan, tales "ataques" habrían venido bajo dos formas principalmente: la legalización y el control de sus bienes. Esto es, las cofradías estaban ahora en la obligación de obtener la licencia real de la que habían carecido para seguir subsistiendo, y sus bienes debían considerarse "civiles", y por tanto también bajo la jurisdicción real, que podría requerirlos para las urgencias del Real Erario ${ }^{12}$.

Sin negar la importancia de las intenciones reformadoras de la Corona en materia de cofradías, al revisar la documentación generada en el Consejo de Indias, es evidente que su alcance y su carácter radical pueden matizarse, como ha sucedido ya con las reformas borbónicas en general. Según ha mostrado la obra de Annick Lempérière, los ministros de la Corona, además de preferir la negociación para implementar su política, se servían para ello en buena medida del propio entramado corporativo ${ }^{13}$. Las cofradías no fueron excepción. Así, en una primera parte veremos los alcances y los mecanismos de los que se sirvió la Monarquía hispánica para emprender la reforma de las cofradías en general y de las novohispanas en particular. Es cierto, sin duda, que había un imperativo por redefinir a las cofradías y su jurisdicción como "cuerpos profanos", pero no pudo marginar por completo a la autoridad episcopal.

Para identificar algunos de los principales temas de la reforma, analizaremos esa misma documentación, en particular los informes de los fiscales del Consejo. Podemos decirlo desde ahora, tales informes muestran, entre otras preocupaciones, la de reforzar el carácter religioso de las cofradías por dos vías: en primer lugar, purificando el culto y reuniéndolo con la caridad, según veremos en el tercer epígrafe, y en segundo lugar separando la devoción de la obligación y de los intereses profanos, lo cual trataremos en el cuarto epígrafe del texto. Por todo ello, la reforma de las cofradías, tal vez más limitada de lo que se ha podido pensar, no podía evitar que siguieran

9 Bazarte - García, 2001, pp. 38-39; Garcia, 2007, p. 119; García, 2010, pp. 267-271.

10 En particular Brading, 1994 y Farriss, 1995; asimismo Mazín, 1987; Jaramillo, 1996; De la Torre, 2001, entre otros. Una síntesis reciente desde esta perspectiva en GARCía, 2010.

11 BRADING, 1994, p. 21.

12 Véase, además de las obras citadas en la nota 8: ZAHÍNO, 1996, pp. 96-101; TAYLOR, 1999, pp. 457-459.

13 Lempérière, 2004, especialmente pp. 142-145. 
siendo parte de los "reinos de la confusión" - por retomar en otro contexto una expresión de Alain Cabantous ${ }^{14}$ - entre lo sagrado y lo profano.

\section{JUNTAS DE LEGOS}

La reforma de las cofradías en la Monarquía Hispánica data de tiempos del reinado de Carlos III, y se llevó a cabo especialmente por dos vías: a través de expedientes generales en los altos tribunales regios, las audiencias y los consejos, y de expedientes particulares de cada cofradía según fueran presentándose las circunstancias. En el Consejo de Castilla fue una representación del obispo de Ciudad Rodrigo en 1768 la que inició el amplio expediente general del que resultará el real decreto de 1783 para su arreglo, reforma y extinción ${ }^{15}$. Los hubo también en otros tribunales peninsulares. En la Real Audiencia de Grados de Sevilla, por ejemplo, en 1776 se abrió un expediente general de cofradías a instancia del fiscal ${ }^{16}$. Hasta donde sabemos, no se formó uno en el Consejo de Indias, en cambio sí lo hubo en la Real Audiencia de México, instruido a solicitud del contador general de propios y arbitrios en el mismo año de $1776^{17}$.

En uno y en otro caso, peninsular o novohispano, la reforma general tenía un fundamento jurídico común: la legislación recopilada. La Nueva Recopilación para los reinos peninsulares, y la Recopilación de Leyes de Indias, para el novohispano, contenían leyes de Enrique IV y Carlos V y de Felipe III y Felipe IV, respectivamente, mandando que no se fundaran cofradías "sin nuestra licencia y autoridad de prelado" ${ }^{18}$. Fue en esa legislación en la que los reformadores se basaron para establecer la jurisdicción real sobre las cofradías. Tal era el cambio que promovían los fiscales de la Corona en cumplimiento del que se entendía como su deber principal, es decir, la protección de las regalías de la Corona. Hasta entonces estas corporaciones habían estado sujetas a la jurisdicción eclesiástica, a partir de ahora "volverían" a la del rey.

Era sin duda éste uno de los temas que más escándalo causaba en los fiscales y magistrados. El conde de Aranda, fiscal del Consejo de Castilla, en 1773 hablará en el expediente general de Madrid de "usurpación de la real autoridad" por parte de la autoridad episcopal ${ }^{19}$, mientras que en el Consejo de Indias el fiscal Antonio Porlier calificará la situación de "abuso" 20 . Pero además de fundamentar la ira de los letrados, la jurisdicción regia evidente en las leyes, servía a los reformadores para definir,

14 Cabantous, 2004.

15 Romero, 1988, pp. 205-207 y 1998 pp. 123-125; Callahan, 1998, pp. 44-46.

16 Expediente general sobre arreglo de hermandades. Sevilla, 1776-1798. Archivo General del Arzobispado de Sevilla (en adelante AGAS), Justicia, Hermandades y cofradías, 09813, 4.

17 LeMPÉRIÈre, 2004, pp. 174-182; analizado a detalle en LuQue, 2003, passim.

18 Se trata de las leyes $3^{\mathrm{a}}$ y $4^{\mathrm{a}}$ del título XIV, libro $8^{\mathrm{o}}$ de la Nueva Recopilación de Leyes de Castilla y de la ley 25 del título IV, libro $1^{\circ}$ de la Recopilación de Leyes de Indias.

19 Citado en Romero, 1998, p. 336.

20 Dictamen del fiscal del Consejo. Madrid 17-X-1776. Archivo General de Indias (en adelante AGI), México, 2661. Como se sabe, en esta época el Consejo contaba con dos fiscales, titulados del Perú y de Nueva España, salvo indicación contraria, nos referimos aquí a este último. 
como hacían incansablemente en estos expedientes, a las cofradías como "cuerpos de legos" o "cuerpos laicales", y por ello tanto más fuera de la jurisdicción eclesiástica. Cofradía no era sino una "junta de legos que se congregan en cierto lugar por causa de algunos ejercicios piadosos", según la definición del fiscal Ambrosio de Sagarzurrieta en Guadalajara en $1790^{21}$.

Es sin duda significativo que, aun partiendo de principios comunes, a diferencia del expediente peninsular, el de México no se concretó en una resolución clara. Cabe destacarlo, no fue sólo por la falta de la cooperación del episcopado, ni por la lentitud de las respuestas de los magistrados de las provincias, sino por una recomendación explícita del fiscal Lorenzo Hernández de Alva en el sentido de preferir la agilidad de los expedientes particulares en lugar de las "muchas y prolijas diligencias" del expediente general ${ }^{22}$. Éste, conformado para entonces por 16 gruesos cuadernos, fue mandado archivar por el virrey conde de Revillagigedo el 6 de diciembre de $1793^{23}$. La reforma pues, quedaba confiada por completo a los expedientes particulares que ya se habían ido formando de manera paralela a las largas diligencias emprendidas desde 1776.

Siguiendo el tenor literal de la ley, las cofradías que, para regularizar su situación o para cualquier otro motivo se presentaban ante el gobierno del virreinato, eran remitidas al Consejo de Indias. Así, entre 1767 y 1820 llegaron a ese tribunal al menos 117 solicitudes de cofradías de los distritos de la Audiencia de México, de la Audiencia de Guadalajara y de la gobernación de Yucatán ${ }^{24}$. A través de esos expedientes se trató de poner en vigor la legislación antes citada, repetida constantemente en cada uno de ellos.

Ahora bien, la vía de los expedientes particulares tampoco significa una diferencia radical de procedimiento respecto al caso peninsular. El real decreto de 1783 no mandaba sino una "recogida de constituciones", es decir, la presentación por parte de las cofradías de sus documentos fundamentales, sus reglas, para ser revisados y reformados caso por caso por las audiencias respectivas y, según su resultado, recibir la licencia del Consejo de Castilla. En consecuencia, también allí se formaron una multitud de expedientes particulares de aquellas cofradías que fueron efectivamente alcanzadas por la reforma ${ }^{25}$.

En lo que sí hubo diferencia fue en los medios utilizados para poner en orden las cofradías. La "recogida de constituciones" peninsular, aun siendo muy desigual en su efectividad, fue operada a través de las autoridades civiles, consumando el desplazamiento de la autoridad episcopal en la materia. Volviendo al ejemplo de Sevilla, fue la

21 Testimonio íntegro de los autos formados sobre los bienes de comunidad que goza cada pueblo de indios de los del distrito de esta intendencia de la provincia de la Nueva Galicia. Guadalajara, 1787-1791. AGI, Guadalajara, 352, 11.

22 Véanse los pedimentos del fiscal Borbón, México, 20-XI-1793 y del fiscal Alva, México, 5-XII-1793, y el decreto del virrey dado en México, 6-XII-1793 en Archivo General de la Nación de México (en adelante AGN), Cofradías y archicofradías, 18, 6, ff. 234-241v.

23 Sobre el desarrollo del expediente en detalle: Luque, 2003, passim.

24 LEMPÉRIĖRE, 2004, p. 177, había advertido ya la importancia de estos expedientes a partir de su resultado: las reales cédulas que de manera constante llegaban al gobierno de México sobre cofradías.

25 Al respecto Romero, 1998, pp. 721-787 para las de Madrid, y Rodríguez, 2006, pp. $198-210$ para Sevilla. 
Real Audiencia de Grados, a través de los tenientes de Asistente de la ciudad y de los justicias de los pueblos de la provincia los que pusieron en ejecución el real decreto en $1787^{26}$. Para Nueva España, en cambio, los expedientes muestran hasta qué punto la reforma dependió de la colaboración de los obispos.

Conviene volver un poco sobre los detalles. El momento decisivo para emprender la reforma en Nueva España por parte del Consejo de Indias, parece haber sido el año de $1776^{27}$, cuando ocupaba la fiscalía Antonio Porlier ${ }^{28}$. Ya antes había habido casos puntuales en que las cofradías acudían al Consejo $^{29}$, pero no a pedir licencia para fundar, sino directamente para la confirmación de sus constituciones, formadas tan sólo con la autoridad del episcopado ${ }^{30}$. Contrario a sus predecesores, quienes no pusieron mayor obstáculo al respecto, desde sus primeros dictámenes Porlier insistió en la necesidad de hacer cumplir la ley "según su orden, recto sentido y verdadera inteligencia".

En su dictamen de 2 de febrero de 1776 para la cofradía de Nuestra Señora Aránzazu de Guadalajara, el fiscal anunciaba el que habría de convertirse en el procedimiento a seguir: tal y como disponía la ley, las cofradías debían obtener primero "la anuencia del diocesano", enseguida "el real beneplácito" en el Consejo, y sólo entonces formar sus constituciones que, "aprobadas por el diocesano y comunicadas al virrey, presidente o gobernador", serían remitidas a Madrid para su revisión ${ }^{31}$. Un dictamen previo, fechado el 11 de octubre de 1775, dado para la cofradía de Santa Catalina Mártir de México, y visto por el Consejo el 9 de septiembre de 1776, dio por resultado una real cédula mandando cumplir las Leyes de Indias en materia de cofradías de forma estricta ${ }^{32}$. De hecho, la cédula incluyó un llamado de atención al provisor del arzobispado de México por no haberlas seguido al pie de la letra en sus dictámenes ${ }^{33}$.

Informada así la jurisdicción eclesiástica, la reforma tuvo lugar gracias al apoyo que le dio durante su largo pontificado el arzobispo de México Alonso Núñez de Haro y Peralta (1772-1800). Lo decía el propio prelado en un informe de 1780: "se ha mandado en los autos de las visitas de todas [las cofradías] desde el año de 1776 [...] que dentro de dos años acudan los oficiales de ellas a solicitar la real licencia y

26 Expediente general sobre arreglo de hermandades, Sevilla, 1776-1798, AGAS, Justicia, Hermandades y cofradías, 09813, 4, ff.. 14 ss.

27 Previamente, en 1767, hubo una cédula real recordando el cumplimiento de la ley recopilada en la materia, citada por ZAHÍNO, 1996, p. 98 y GARCíA, 2010, p. 267, pero no hemos podido identificar el expediente de su gestación.

28 En los nombres de los fiscales del Consejo de Indias para Nueva España hasta 1808 seguimos a BERNARD, 1972, pp. 226-227

29 Se trataba, por ejemplo, de las cofradías sacramentales de algunas parroquias recién erigidas o recién secularizadas en el arzobispado de México, (la de Santo Tomás de México, la de San Sebastián en Querétaro) producto de las reformas del arzobispo Francisco Antonio Lorenzana. Véase LeMPÉRIÈRE, 2004, pp. $174-182$.

30 Desde luego la mayoría de las cofradías novohispanas de la época ni siquiera llegaba a presentar sus constituciones ante el Consejo.

31 Dictamen del fiscal del Consejo, Madrid, 2-II-1776, AGI, Guadalajara, 370.

32 Expediente de la cofradía de Santa Catalina, AGI, México, 2661.

33 Resolución del Consejo, Madrid, 9-IX-1776 y carta del provisor del arzobispado de México al conde de Val de Llano, México, 30-XII-1776, AGI, México, 2661. 
aprobación de Vuestra Majestad" ${ }^{34}$. La mejor prueba de ese respaldo es que de los 117 expedientes que hemos localizado, 76 proceden del arzobispado de México. Desde luego, monseñor Haro y Peralta no estuvo solo: otro prelado que colaboró, aunque de manera muy puntual, fue el obispo de Puebla Salvador Biempica y Sotomayor (1790-1802), cuyo auto de visita de las cofradías de la ciudad de Veracruz en febrero de 1792 obligó a la presentación de ocho de ellas ante el Consejo de Indias ${ }^{35}$. Cierto, hubo también casos en que las cofradías acudieron a Madrid por orden de la autoridad civil $^{36}$, pero no hubo en todo este período ningún procedimiento general semejante a la "recogida de constituciones" peninsular.

Los fiscales pues, dependían del episcopado para la reforma, pero ello no parece haber limitado su voluntad de introducir cambios. A lo largo de los años, con los sucesivos expedientes se fue formalizando una práctica para su tratamiento. En primer lugar, más que de su supresión, se trató casi siempre de su reforma. Hubo algunas excepciones, sobre todo bajo la fiscalía de Ramón de Posada a finales del siglo ${ }^{37}$; sin embargo, desde la fiscalía de Porlier, el proceso seguido por los expedientes era básicamente el mismo. El Consejo recibía la solicitud de una cofradía, reciente o fundada desde años atrás, para la confirmación de sus constituciones, y la remitía al fiscal de Nueva España. Éste, "atendido el rigor de las leyes" hacía notar que debía negarse el pedimento y suprimirse por faltar la licencia real para la fundación; pero considerando, ya fuera su antigüedad, o bien que contaban con la licencia del ordinario eclesiástico, o simplemente porque sus fines estaban dedicados al culto divino, recomendaba que se autorizara a redactar nuevas reglas, presentarlas al obispo para su aprobación y al gobierno del reino para su examen y reforma. Este último debía enviar el expediente así instruido de vuelta al Consejo, donde sería examinado por el fiscal una segunda vez, y según su dictamen se expediría una real cédula, normalmente aprobatoria, pero modificando algunos detalles de las constituciones ${ }^{38}$.

Esto es, ya en sus procedimientos, la reforma mantenía como principales actores involucrados en las cofradías, tanto al gobierno del virreinato como al episcopado, tanto a los magistrados civiles (quienes debían vigilar la ejecución de las reales cédulas) como a los clérigos. En sus dictámenes, los fiscales solían incluir algunas normas adicionales para guiar la redacción de las constituciones. Fue así como surgieron las que terminarían siendo llamadas "prevenciones ordinarias", que no hacían sino reforzar la jurisdicción regia y la definición de las cofradías como cuerpos de legos.

34 Carta del arzobispo de México al rey, México, 20-V-1780, AGI, México, 2664. Para esta colaboración y para la reforma emprendida por parte del arzobispo Haro, véase ZAHíNO, 1996, pp. 89-110; LEMPÉRIÈRE, 2004, pp. 178-179 y GarCíA, 2007, pp. 111-119.

35 Se trata de la Santa Escuela de Cristo, la Archicofradía del Cordón de San Francisco de Asís y las cofradías de Jesús Nazareno, San Benito de Palermo, San José, Humildad y Paciencia de Cristo, Rosario de Ánimas y San Diego de Alcalá. AGI, México, 1304, 1306, 1308 y 2671.

36 Un ejemplo muy claro, la de Nuestra Señora del Carmen de Salvatierra, obligada a presentarse por estar involucrada en un litigio sobre cuestación de limosnas ante la Audiencia de México. AGI, México, 2676.

37 El fiscal pidió la supresión de cinco cofradías entre 1795 y 1798: las del Espíritu Santo y San José en Querétaro, la sacramental de Huajolotitlán, la de las Cinco Llagas de Guadalajara y la del Alumbrado de Aguascalientes. Dictámenes del fiscal del Consejo. Madrid, 10-III-1795, 6-VI-1795, 26-III-1796, 15-V-1796, 25-X-1798. AGI, México, 2672, 2674 y 1317 y Guadalajara, 376.

38 Véase por ejemplo el dictamen del fiscal del Consejo para la cofradía sacramental de Teotihuacán. Madrid, 4-V-1781. AGI, México, 2664. 
Las dos más repetidas, ya en la década de 1780, fueron: que en adelante todos sus litigios debían seguirse por la justicia civil y no por la eclesiástica y que sus bienes, conforme al carácter de la propia corporación, debían ser considerados profanos y no "espiritualizados" 39 . A consecuencia de un incidente en la formación de las constituciones de la Congregación de Cocheros del Santísimo Sacramento de la parroquia de Santa Catalina mártir de México, el fiscal Juan Antonio de Uruñuela habría de agregar en 1791 que la real jurisdicción se extendería no sólo a las juntas de las cofradías ya formadas, como disponía la ley recopilada, sino también a las juntas preparatorias para la redacción de nuevas constituciones ${ }^{40}$. En suma pues, el primer gran objetivo de la reforma era poner a las cofradías bajo la jurisdicción civil.

Aunque no concretó una norma precisa, el fiscal Uruñuela estaría atento además a que las cofradías se mostraran efectivamente como cuerpos de legos, libres de la voluntad de los clérigos. En 1790 pidió por ello la supresión del hábito previsto en las constituciones de la congregación de Agonizantes de México, que recordaba en exceso el de los padres camilos, para no "dar motivo a que se repute por eclesiástica la congregación de que son individuos" ${ }^{41}$. Al año siguiente reprocharía en la solicitud de licencia para la cofradía sacramental de Tecomic la presencia del párroco, "porque consta que ejecutan esto por su influjo" ${ }^{42}$, por lo que pediría una averiguación detallada de su necesidad por el gobierno de México.

A partir de 1796, bajo la fiscalía de Ramón de Posada y Soto, las prevenciones aumentarían, siempre ganando terreno la jurisdicción regia. Retomando los puntos que había formado el fiscal de la Audiencia de México, el ya citado Lorenzo Hernández de Alva, para la reforma de las constituciones de la cofradía de Santa Catalina de la parroquia de San Miguel, quedaba bajo la autoridad civil autorizar el traslado de una cofradía a otra iglesia, la revisión de sus cuentas anuales y la autorización de sus elecciones a través de un escribano público en lugar de un notario eclesiástico ${ }^{43}$. Posada retomaría estas prevenciones y las iría perfeccionando en sucesivos expedientes, previendo por ejemplo que los superiores de las cofradías debían ser seglares y no eclesiásticos, y que aquellas con constituciones confirmadas pudieran absorber a las otras de la misma iglesia ${ }^{44}$. En tiempos de su sucesor, que no fue otro que el propio Hernández de Alva, el Consejo culminaría los sucesivos arreglos, utilizando la experiencia acumulada en la reforma de las cofradías novohispanas para arreglar las de todos los reinos de Indias.

39 Fueron agregadas por el propio Consejo a las constituciones de la cofradía de Nuestra Señora de Covadonga y de la congregación de Cocheros del Santísimo Sacramento de Veracruz, respectivamente en resolución del Consejo. Madrid, 18-III-1784. AGI, México, 1278 y resolución del Consejo. Madrid, 11-V1789. AGI, Indiferente, 191.

40 Cabe decir, siguiendo en ello al fiscal de México que vio el expediente, Lorenzo Hernández de Alva. Dictamen del fiscal del Consejo. Madrid, 6-VI-1790. AGI, México, 2669 y real cédula dada en Madrid, 8-III1791. AGI, Indiferente, 191.

41 Dictamen del fiscal del Consejo. Madrid, 27-V-1790. AGI, México, 2669.

42 Dictamen del fiscal del Consejo. Madrid, 8-VI-1791. AGI, México, 1306.

43 Minuta de la real cédula dada en Sevilla. 27-II-1796. AGI, México, 2669

44 Véanse en particular los dictámenes dados en los expedientes de la cofradía sacramental y de Ánimas de Atotonilco. AGI, México, 2647 y de la cofradía de Nuestra Señora de los Dolores de Acatzingo. AGI, México, 2650. 
En efecto, en septiembre de 1802 el fiscal Alva, retomando lo hecho por su antecesor, reunió varios expedientes, aplicándoles a todos un mismo listado de prevenciones, que saldrían aprobados por el Consejo en tres cédulas reales dadas el 27 de diciembre de ese $a n ̃ o 0^{45}$. Una de ellas, la que mandaba la reforma de la cofradía de las Benditas Ánimas del pueblo de Santiago Calimaya, serviría a su vez de modelo para formar una real cédula general, la del 15 de octubre de 1805, con una lista definitiva de diez prevenciones ${ }^{46}$. En ella quedaba definitivamente asentado que era a la autoridad del rey y no a la episcopal a quien correspondía todo el arreglo de "cofradías, hermandades o congregaciones", y aunque no incluía una definición explícita de ellas, su carácter lego es más que evidente en la exclusión definitiva de sus cargos y gestión a los clérigos o cualquier persona del fuero eclesiástico.

Así, aunque extremadamente limitada en sus alcances, la reforma de las cofradías novohispanas por expedientes particulares había logrado la conclusión que no tuvo el expediente general de México, y que no era destruir las cofradías, sino declararlas por punto general como juntas de legos, asunto profano pues, y por tanto de las regalías de la Corona. Sin embargo, los expedientes muestran también que los objetivos de las reformas borbónicas en esta materia no se limitaban al tema de la jurisdicción y naturaleza de estos cuerpos, sino que alcanzaban los detalles de su organización, insistiendo en reforzar su carácter religioso, como veremos a continuación.

\section{OBRAS DE CARIDAD}

En la segunda mitad del siglo XVIII comenzó en el mundo hispánico, de manera incipiente, el desliz de la caridad tradicional hacia la beneficencia moderna ${ }^{47}$, por lo que no es de extrañar que otro de los grandes objetivos de la reforma de las cofradías bajo los Borbones fuera justamente la promoción de la caridad. La real resolución de 1783, mandaba la formación de Juntas de Caridad por todo el reino, en las ciudades capitales de los obispados, provincias y partidos, siguiendo el modelo de las que se había ordenado establecer ya en Madrid en $1778^{48}$. En principio, eran esas juntas las que se encargarían de examinar la situación de las cofradías de sus respectivos territorios, y sobre todo de los bienes de aquellas que debían extinguirse para dedicarlos a la formación de montepíos, o "a socorro de los pobres" ${ }^{49}$. Desde luego, la reforma no logró implantarse de inmediato, antes bien hubo algunos intentos de crearlas, ya que no había sido posible hacerlo ex nihilo, a partir de alguna de las propias cofradías cuyo instituto fuera la caridad, adaptando simplemente sus constituciones a la legislación dada para ellas. Tal fue el proyecto del fiscal de la Audiencia de Grados de

45 Dictámenes del fiscal del Consejo. Madrid, 3-IX-1802, para las cofradías sacramental de Tlapacoyan (AGI, México, 2692), de San Homobono de México (AGI, México, 2683), de Ánimas de Calimaya (AGI, México, 2651) y de Nuestra Señora del Tránsito de Durango (AGI, Guadalajara, 577). Lempérière, 2004, p. 177, ya hizo notar la importancia de la real cédula de 1802 como culminación del proceso de reforma.

46 Real cédula dada en San Lorenzo. 15-X-1805. AGI, México, 3096A.

47 Para el tema de la reforma de la caridad en Nueva España véase Lempérière, 2004, pp. 183-191.

48 Romero, 1998, pp. 255-262.

49 La real resolución en Ibídem, pp. 900-910. 
Sevilla para las congregaciones caritativas fundadas en las parroquias de San Vicente y San Miguel de esa ciudad, ya a principios del siglo XIX ${ }^{50}$.

El tema de la caridad estuvo también presente en las discusiones en la Nueva España. De hecho, en 1790 el fiscal de la Audiencia de Guadalajara, Ambrosio de Sagarzurrieta, proponía seguir el ejemplo castellano creando, ya que no una red de juntas de caridad, al menos una junta provincial que se encargara de la reforma de las cofradías $^{51}$. En el Consejo de Indias, entre 1793 y 1806, fueron los fiscales Ramón de Posada y Lorenzo Hernández de Alva quienes trataron de dirigir a las cofradías novohispanas hacia fines caritativos.

Conviene recordar que las cofradías novohispanas presentadas ante el Consejo de Indias en la época que tratamos estaban destinadas fundamentalmente al culto divino, ya fuera del Santísimo Sacramento, de las Ánimas del Purgatorio, o de algún santo o advocación mariana. Esto es, estaban dedicadas principalmente a organizar las diversas "funciones de iglesia", como se decía en la época, propias de su devoción, y también salidas por las "calles públicas". Por ejemplo, el culto del Santísimo implicaba normalmente la misa de renovación semanal los jueves, la instalación del monumento el Jueves Santo, su acompañamiento en sus salidas para el viático y para el cumplimiento del precepto anual por los enfermos e impedidos, y desde luego, la fiesta principal de Corpus Christi ${ }^{52}$. En honor de las Ánimas del Purgatorio se organizaba también una misa semanal los lunes, además de algún aniversario solemne en la octava de la fiesta de los Fieles Difuntos ${ }^{53}$. En honor de las "soberanas imágenes" se celebran también sus respectivas fiestas con el boato posible según los recursos de cada una: había desde grandes solemnidades con vísperas, misa cantada oficiada por preste, diácono y subdiácono, con músicos, sermón, procesión, y funciones en la novena y en la octava, hasta celebraciones más bien modestas, con una sola misa y procesión ${ }^{54}$.

La caridad, por tanto, sin estar del todo ausente de las constituciones de las cofradías, ocupaba un lugar más bien marginal respecto del culto. Los cofrades solían practicar algunas obras de misericordia, como las oraciones y ayuda para entierros de sus propios hermanos; algunas contaban también con dotes que se sorteaban para las huérfanas ${ }^{55}$, o con limosnas para los pobres de la parroquia ${ }^{56}$. Los fiscales Posada

50 Expediente formado en virtud de provisión del Consejo para que se informe en solicitud de dicha congregación sobre aprobación de sus ordenanzas, Sevilla, 1804 y Expediente formado en virtud de provisión del Consejo para que se informe en pretensión de la hermandad de caridad establecida en la parroquia de San Vicente, Sevilla, 1817, ambos en AGAS, Justicia, Hermandades y Cofradías, 09801, 17.

51 Véase el dictamen de 29-III-1790 en el Testimonio íntegro de los autos formados sobre los bienes de comunidad que goza cada pueblo de indios de los del distrito de esta intendencia de la provincia de la Nueva Galicia. Guadalajara, 1787-1791. AGI, Guadalajara, 352, 11.

52 Un buen ejemplo de este culto está en las constituciones de la cofradía sacramental de Tulyahualco: Testimonio de los documentos presentados por la cofradía del Santísimo Sacramento del pueblo de Tulyahualco, .México, 1782, fols. 7-12. AGI, México, 2664.

53 Otro ejemplo clásico: Testimonio del expediente formado sobre aprobación de las constituciones de la cofradía de Señor San José y Benditas Ánimas de la parroquia del pueblo de Calimaya. México, 1802. AGI, México, 2651. ff. 3-7v.

54 García, 1999, passim; TAYlor, 1999, p. 454.

55 Por ejemplo, la de San José de Veracruz. AGI, México, 2671.

56 Era el caso de la Santa Escuela de Cristo de la propia ciudad de Veracruz. AGI, México, 1306. 
y Alva percibieron bien esta situación, y trataron de ampliar y generalizar la práctica de la caridad en las cofradías.

No es que los letrados al servicio del Consejo menospreciaran la importancia del culto. Aun cuando a lo largo de esos más de 50 años cada uno de los fiscales para Nueva España mostró preocupaciones específicas, todos reconocieron la utilidad y necesidad del culto que las cofradías organizaban. Así, la cofradía de Nuestra Señora de Covadonga mereció la aprobación de sus constituciones por el fiscal Porlier en 1784 en razón de sus "piadosos, útiles y devotos fines" ${ }^{57}$, y la sacramental del pueblo Chilcuautla obtuvo la de su sucesor, el fiscal Juan Antonio Uruñuela, "por lo mucho que contribuyen al fomento del culto" 58 . Lo dirá, en fin, con toda claridad el fiscal Posada en su dictamen aprobando las del pueblo de Tecomic: "las cofradías del Santísimo Sacramento y Benditas Ánimas del Purgatorio se dirigen a un objeto sumamente recomendable y piadoso" 5 .

Así, si bien las reglas de la cofradía de la Purísima Concepción de Querétaro disponían ya dotar a una huérfana, ello era sólo cuando sus sobrantes excedían los 300 pesos. Por ello, el fiscal Posada dictaminó en 1796 que debían reducir sus gastos para dotar a cuantas más fuera posible ${ }^{60}$. Unos meses más tarde, el letrado optó por ir más lejos en sus requerimientos. A la cofradía de Ánimas de Tenancingo, que pedía licencia para formar sus constituciones, le recomendó que en ellas se limitara el culto a "una sola función anual", dejando así lugar a que la mayor parte de sus fondos se dedicaran a "otras obras de verdadera caridad" ${ }^{61}$. Al año siguiente, el dictamen para la cofradía de Nuestra Señora del Rosario de Iztapaluca fue más preciso aún: debían destinar sus sobrantes a fundar una escuela pública, o a completar la dotación de la que ya existiera, o bien al sustento de niños expósitos ${ }^{62}$. Este último punto se repetiría en su dictamen para la congregación de San José de Querétaro ${ }^{63}$, mientras que a las cofradías de la Santísima Trinidad y Santo Ángel de la Guarda de la misma ciudad y a la de Nuestra Señora del Tránsito de Durango recomendaría la apertura de una escuela gratuita para niñas ${ }^{64}$.

Una idea clara de los gastos que Posada estimaba necesarios reducir en materia de culto aparece en su dictamen de la cofradía de San Crispín, San Aniano y San Crispiniano de Puebla de junio de 1797. El problema era el exceso de gasto en cera. Como se sabe en la sensibilidad religiosa de la época, el culto iba íntimamente asociado a la iluminación ${ }^{65}$. Ello valía tanto para el Santísimo Sacramento, permanentemente alumbrado por una lámpara de aceite, como para las imágenes, en cuyas fiestas debía brillar el mayor número posible de cirios, velas y hachas. Los cofrades habían establecido en sus constituciones una iluminación de un total de 62 luces, entre velas

57 Dictamen del fiscal del Consejo. Madrid, 13-III-1784. AGI, México, 1282.

58 Dictamen del fiscal del Consejo. Madrid, 31-III-1791. AGI, México, 2670.

59 Dictamen del fiscal del Consejo. Madrid, 3-XI-1793. AGI, México, 1306.

60 Dictamen del fiscal del Consejo. Madrid, 24-VIII-1796. AGI, México, 1311

61 Dictamen del fiscal del Consejo. Madrid, 19-XII-1796. AGI, México, 2574.

62 Dictamen del fiscal del Consejo. Madrid, 22-II-1797. AGI, México, 2674.

63 Dictamen del fiscal del Consejo. Madrid, 17-V-1797. AGI, México, 2674.

64 Dictamen del fiscal del Consejo. Madrid, 23-VIII-1798. AGI, México, 2671. Dictamen del fiscal del Consejo. Madrid, 16-IX-1798. AGI, Guadalajara, 577.

65 Un tema abordado en varias de las colaboraciones reunidas en DOMPNIER, 2009. 
y cirios, sobre el altar y delante de él en la fiesta principal, a más de otras 24 para el túmulo de la conmemoración de difuntos ${ }^{66}$. Tales luces parecieron "excesivas" al fiscal, no sólo por la inversión en ellas, cabe decir, sino también por la "moderación" que estimaba debía caracterizar al culto. Siendo esta una cofradía gremial, de los zapateros de la ciudad, recomendó que lo disminuido en cera se destinara al auxilio de los enfermos, inválidos, viudas y huérfanos de dicho oficio ${ }^{67}$.

Similar fue el caso de la sacramental de Santiago de Querétaro, que dedicaba sus fondos sobre todo a misas y funciones y nada a la caridad, fuera de asistir a los bienhechores de la propia cofradía ${ }^{68}$. Ello era reprensible, decía el fiscal, porque "cuanto se recoja ha de venir o parar en un párroco que tiene el beneficio más pingüe del arzobispado y no lo necesita, como otros, para su sustento"69. La moderación del gasto del culto iba pues también dirigida a moderar la extracción de recursos de los fieles por parte de los párrocos, tema que aparecerá de otras formas tanto en las discusiones de los expedientes generales, como en otros litigios particulares de las cofradías de la época ${ }^{70}$.

Como puede advertirse, para el fiscal Posada la reforma por esta vía, "conciliando la solemnidad del culto con la atención que merece la caridad con el prójimo necesitado", era fundamental. Resultaba además un camino tanto más práctico cuanto que era introducir cambios "insensiblemente", es decir, sin suscitar reacciones adversas, y del que se prometía ya los mejores resultados. Gracias a estas modificaciones, decía: "se sacará de ellas un nuevo fruto, muy del agrado de Dios, que cederá al mismo tiempo en beneficio del Estado" 71 .

Empero, el Consejo no siempre se conformaba con esta nueva orientación para las cofradías. A veces ampliaba lo pedido por Posada, como fue en el caso de Iztapaluca, en que la sala declaró "haber parecido excesivo el número de funciones eclesiásticas"; en cambio, en los expedientes de Tenancingo, San José y la sacramental de Santiago de Querétaro no aceptaron los dictámenes ${ }^{72}$. Aún más, en los últimos años del siglo XVIII y primeros del XIX, el tema de la caridad no llegó a incluirse en las prevenciones generales que se formaron bajo la fiscalía de Lorenzo Hernández de Alva.

Entre los expedientes que el fiscal examinó el 3 de septiembre de 1802 estaba, como hemos mencionado antes, el de la cofradía de San José y Ánimas Benditas del pueblo de Santiago Calimaya. Siguiendo el precedente de Posada, Alva sugirió reducir las limosnas establecidas para la ayuda de los entierros de los cofrades, no menos que los gastos de culto. Sin ser específico, dictaminó que los sobrantes debían dedicarse "en socorro de los pobres, presos o enfermos, o en otra cosa útil al

66 Testimonio del expediente sobre constituciones de la cofradía de San Crispín, San Aniano y San Crispiniano, fundada en la iglesia parroquial de San José de Puebla. México, 1796. AGI, México, 2673.

67 Dictamen del fiscal del Consejo. Madrid, 11-VI-1797. AGI, México, 2673.

68 Testimonio del expediente sobre aprobación de las constituciones de la archicofradía del Santísimo Sacramento de la ciudad de Querétaro. México, 1798, AGI. México, 2672.

69 Dictamen del fiscal del Consejo. Madrid, 24-XII-1799. AGI, México, 2672.

70 ZAHÍNO, 1996, pp. 96-98; TAYLOR, 1999, pp. 460-470.

71 Dictámenes del fiscal del Consejo. Madrid, 19-XII-1796 y 24-XII-1799. AGI, México, 2674 y 2672

72 Resoluciones del Consejo. Madrid, 10-I-1797, 18-III-1797, 20-V-1797 y 6-XI-1799. AGI, México, 2674 y 2672. 
vecindario"73. Esta disposición se insertó en la real cédula de 27 de diciembre de 1802 como la undécima de las 13 prevenciones para la cofradía, permitiendo a la mesa de la propia corporación opinar en cuanto al destino a darle a los sobrantes ${ }^{74}$. Esta cédula sirvió, como ya hemos dicho, para redactar la general de octubre de 1805 para todas las cofradías de los reinos de Indias, y se copiaron puntualmente diez de sus puntos, pero excluyendo justamente el que mandaba la reducción de gastos en beneficio de la caridad al público ${ }^{75}$.

A pesar de lo anterior, la real cédula dada para el caso de Santiago Calimaya sirvió de modelo en la corrección de constituciones que efectuaba la Audiencia de México. Los fiscales de lo civil del tribunal la impusieron como guía para redactar las constituciones de las cofradías sacramental de Ixtlahuaca en $1805^{76}$, sacramental de Malinalco en $1806^{77}$, sacramental de San Agustín del Palmar y de Cocheros del Santísimo de la parroquia de San Sebastián de México en $1817^{78}$. Además, las propias cofradías la retomaron antes incluso de que les fuera indicado por la Audiencia. Así, la cláusula sobre reducción de gastos de culto en beneficio de la caridad aparece en la constitución undécima de las presentadas por la cofradía del Señor de los Trabajos de Querétaro, formadas a finales de $1803^{79}$.

Por supuesto, hubo también iniciativas del clero en ese sentido. Tal vez la más alabada de las cofradías novohispanas que se presentaron al Consejo fue la proyectada en 1794 por el doctor José Miguel Guridi y Alcocer ${ }^{80}$, por entonces párroco de Acajete, titulada "cofradía de la Piedad". Ella concentraría las limosnas de sus hermanos y en general de todos feligreses para dedicarla a socorrer a los "pobres inválidos" del pueblo con alimentos y ropa, pudiendo también hacer préstamos sin interés ${ }^{81}$.

En fin, el propio fiscal Hernández de Alva y sus sucesores, los últimos ministros fiscales del Consejo, continuaron haciendo referencia a la cédula de 1802. Junto al caso de Calimaya, Alva la impuso también en la sacramental de Tlapacoyan, en la de Ánimas de Malinalco, en la de San Homobono de México y en la de la Coronación de

73 Dictamen del fiscal del Consejo. Madrid, 3-IX-1792. AGI, México, 2651.

74 Minuta de la real cédula dada en Cartagena. 27-XII-1802. AGI, México, 2651

75 Real cédula dada en San Lorenzo. 15-X-1805. AGI, México, 3096A.

76 Testimonio del expediente formado a consecuencia de la real cédula sobre formación de constituciones de la cofradía del Santísimo Sacramento de Ixtlahuaca para su aprobación. México, 1806. AGI, México, 2693. ff. 14-17v.

77 Testimonio del expediente promovido por el mayordomo y diputados de la cofradía del Santísimo Sacramento y Nuestra Señora de los Dolores de la parroquia del pueblo de Malinalco sobre aprobación de las constituciones de dicha cofradía. México, 1806. AGI, México, 2651. ff. 21v-25v.

78 Testimonio del expediente formado sobre aprobación de las constituciones de la archicofradía del Divinísimo Señor Sacramentado de la iglesia parroquial de San Agustín del Palmar. México, 1818. AGI, México, 1302. Testimonio del expediente promovido por el cochero mayor de los distinguidos del Santísimo de la Parroquia de San Sebastián, sobre aprobación de sus constituciones. México, 1819. AGI, México, 2702.

79 Testimonio del expediente promovido por los cofrades de la cofradía del Señor de los Trabajos sobre que se les permita trasladarla al colegio de niñas educandas de Querétaro y que reconocidas sus constituciones se apruebe por S.M. según está prevenido. México, 1804. AGI, México, 2787. ff. 1v-5.

80 Personaje bien conocido en la historiografía mexicanista por su participación, años más tarde, como diputado en las Cortes de Cádiz, en las de 1820 y los primeros congresos constituyentes del México independiente.

81 Testimonio del expediente formado a pedimento del cura y justicia del pueblo de Acajete sobre fundar una cofradía con el título de Piedad. México, 1796. AGI, México, 1312. 
Real del Monte ${ }^{82}$. Cabe decir, esta última fue acaso la única que se mostró realmente reticente a incluir este tipo de prevención en sus constituciones, por lo que el fiscal hubo de recordarlo al menos en otras dos ocasiones.

El Consejo autorizó la mayor parte de estos dictámenes, pero ello no quiere decir que la reforma estuviera garantizada. Lo ilustra bien el último de los expedientes en que se pidió la reducción de gastos de culto en beneficio de la caridad, el de la cofradía de Nuestra Señora del Carmen del convento carmelita de San Sebastián de México. El fiscal sugirió que los sobrantes, destinados en las constituciones al adorno del altar de la Virgen en la fiesta anual, se repartieran a los pobres enfermos, "pues éste es un destino más análogo al fin de estas piadosas asociaciones"83. El 13 de noviembre de 1818, a pesar de la ya larga experiencia aplicando este tipo de reforma, el Consejo resolvió omitir "toda expresión referente al uso que debe hacerse de los fondos sobrantes" $" 84$.

Debemos subrayarlo: los fiscales Posada, Alva y sus sucesores, se valieron siempre de argumentos tanto religiosos como de utilidad pública para encaminar los sobrantes de las cofradías del culto a la caridad. Lejos de tratar de secularizar a las cofradías con esta reforma, desde su perspectiva no hacían sino corregirlas en sus deberes religiosos. Algo similar ocurría cuando se trataba del cumplimiento de algunas otras responsabilidades de los oficiales de estas corporaciones.

\section{CONGREGACIONES PIADOSAS}

Aunque en ciertas regiones no era raro que las cofradías novohispanas se convirtieran en una responsabilidad individual; es decir, que el mayordomo o el párroco mismo se quedaran solos como únicos administradores, idealmente las autoridades tanto civiles como eclesiásticas esperaban que se organizaran efectivamente como corporaciones. En tanto tales, debían ser encabezadas por una junta o mesa de varios oficiales, renovados de manera anual ${ }^{85}$. Los nombres de los cargos podían variar ampliamente de una a otra, habiendo por lo general un principal (hermano mayor, rector, prior, prioste o mayordomo), acompañado de un consejo (diputados, conciliarios) y/o de cargos específicos (tesorero, secretario, celador). La descripción de sus funciones solía ocupar un largo espacio en las constituciones, a veces detallando una a una sus responsabilidades, que no eran pocas y a veces constituían una pesada labor.

En efecto, los oficiales eran ni más ni menos que los responsables de la administración de los bienes de la cofradía y del cumplimiento de sus obligaciones. Los bienes podían consistir desde sólo las limosnas de ingreso y anuales (cornadillos o jornali-

82 Dictamen del fiscal del Consejo. Madrid, 3-IX-1802. AGI, México, 2692; Testimonio del expediente promovido por el mayordomo y diputados de la cofradía del Santísimo Sacramento y Nuestra Señora de los Dolores de la parroquia del pueblo de Malinalco sobre aprobación de las constituciones de dicha cofradía, AGI, México, 2651. ff. 10v-17; Dictamen del fiscal del Consejo. Madrid, 12-V-1803. AGI, México, 2683; Dictamen del fiscal del Consejo. Madrid, 24-IX-1802. AGI, México, 2682.

83 Dictamen del fiscal del Consejo. Madrid, 9-XI-1818. AGI, México, 2701.

84 Resolución del Consejo. Madrid, 13-XI-1818. AGI, México, 2701.

85 Hay descripciones de la organización de las cofradías en BAZARTE, 1989, pp. 51-63; ZAHÍNO, 1996, pp. 93-96; TAYLOR, 1999, pp. 450-451, entre otros. 
llos) de los hermanos, hasta ganado, casas y tierras, o inclusive rentas y obras pías. Había que ocuparse por tanto de recaudar limosnas, rentas y alquileres, procurando el buen mantenimiento de las casas, a veces también de la correcta explotación de los hatos ganaderos, y de la distribución de las tierras para su cultivo. Debían, claro está, pagar las misas, los funerales de los hermanos y demás funciones de iglesia, tanto a los clérigos que oficiaban como a los cantores, sacristanes e instrumentistas que les acompañaban, cuidando de la cera y alhajas con que se adornaban sus imágenes y devociones, y por supuesto, pagar también -a pesar de los reproches de las autoridades- banquetes y refrescos en los días de fiesta y de rodeo y conteo del ganado. En principio se esperaba que llevaran una administración de ordenada de todo ello en libros, cuyas cuentas anuales serían revisadas por el conjunto de los cofrades reunidos en cabildo anual, siendo responsables personalmente de los "desfalcos" que pudieran ocurrir a lo largo de su gestión ${ }^{86}$.

No era fácil, por tanto, ser oficial de cofradía, de ahí que algunas de ellas establecieran en sus constituciones algún pago a sus cobradores y administradores, a fin de retribuirles su trabajo. Asimismo, se establecían fianzas para garantizar que sus bienes estarían a resguardo, o directamente se buscaba a los notables locales que tuvieran capacidad para afrontar los gastos. Además, para respaldar unos bienes siempre precarios, se establecían multas a quienes no cumplieran con sus cuotas y se cuestaban limosnas, no sólo entre los cofrades sino entre el público, para aumentar sus ingresos. Sin embargo, como en el caso del culto divino, todo ello fue visto por parte de los fiscales y consejeros indianos como un "exceso" en "congregaciones piadosas", en las cuales, según se desprende por sus dictámenes, debía imperar el carácter voluntario y gratuito de toda participación.

Esta tendencia fue especialmente clara en el caso de las limosnas, en primer lugar, las que recaudaban entre los propios cofrades, las cuales no podían ser obligatorias, sino voluntarias. En ese sentido iba ya el propio Consejo, primero en las correcciones que hizo a las constituciones de la Cofradía del Santo Cristo de Burgos en 1775, definiendo la cuota de ingreso como "limosna voluntaria" ${ }^{87}$. Más tarde, en la reforma de la Congregación de Cocheros del Santísimo Sacramento de Veracruz en 1789, moderaría las cuotas, y si bien mantuvo la obligatoriedad de las de ingreso, declaró voluntarios los aumentos que los congregantes habían incluido en la reforma de sus reglas $^{88}$.

De nuevo fueron los fiscales de finales de siglo quienes más se interesaron en este punto. Posada volvió sobre el tema en dos ocasiones en el expediente de la sacramental de Huajolotitlán, que reunía tanto a los españoles como a los indios de dicha parroquia, estableciendo cuotas separadas para cada grupo. En 1798, el fiscal determinó que las cuotas de los indios debían ser "según les sugiera su voluntad, que es mucha", por lo que el fiscal de México efectivamente impondría una cuota de ingreso voluntaria para ambos, españoles e indios, pero manteniendo ciertos mínimos. Ello no fue suficiente para el fiscal del Consejo, quien en 1800 reafirmó que la cuota de los

\footnotetext{
2004.

86 Además de los anteriores, centrándose en el tema de la administración de bienes: TANCK, 2004 y GARCÍA,

87 Resolución del Consejo. Madrid, 13-IX-1775. AGI, México, 1765.

88 Resolución del Consejo. Madrid, 13-V-1789. AGI, Indiferente, 191.
} 
indios fuere "según les dictare su piedad y permita su miseria", estableciendo no una cuota mínima sino una máxima de dos pesos ${ }^{89}$. El fiscal Alva, quien ya como fiscal en México había corregido "los visos que tenía de penal" la contribución de entrada de los cocheros del Santísimo Sacramento de la parroquia de San Pablo de México ${ }^{90}$, fue quien dio el paso final a esta reforma. En 1802, estableció finalmente en las constituciones de la cofradía de Ánimas de Calimaya que todas sus contribuciones debían ser tenidas por voluntarias ${ }^{91}$, sirviendo esta reforma, como hemos dicho antes, como modelo para las demás cofradías novohispanas, por ejemplo la de Nuestra Señora de las Mercedes de Querétaro ${ }^{92}$.

Aparte de las cuotas de los cofrades, Posada y Hernández de Alva insistieron en que las limosnas cuestadas en el público no fueran exigidas por los colectores, sino ofrecidas voluntariamente por los fieles ${ }^{93}$. El primero encontró en 1796 que la congregación de Nuestra Señora de los Dolores de la parroquia del Sagrario de México establecía en sus constituciones cuestores por las calles para recoger limosnas de los fieles, aunque "sin penarlos ni obligarlos". Radical, el fiscal borró directamente la constitución que prevenía dicha práctica, justificando su dictamen con las Leyes de Indias, la Recopilación de Castilla y el propio Concilio de Trento, no dejando sin embargo de alabar una "obra piadosa muy recomendable" 94 .

Al año siguiente, sin embargo, en los expedientes de la cofradía de Nuestra Señora del Rosario de Iztapaluca y de la sacramental y del Rosario de San Luis Potosí, Posada habría de establecer la que sería la práctica corriente: la limosna habría de recogerse exclusivamente en el pórtico de las iglesias del curato respectivo, sólo durante las festividades, colocando para ello una bandeja, custodiada por dos congregantes, "para que reciban la limosna que se ofrezca voluntariamente" 95 . El fiscal hizo lo mismo en el expediente de la cofradía del Carmen de Salvatierra, imponiendo así una norma que ya se había establecido en las cofradías de Madrid, y dejando claro que no se trataba de una cuestación, pues los cofrades estarían ahí "sin pedir", sino simplemente recibiendo según la voluntad de los fieles ${ }^{96}$.

Voluntaria, y por tanto desinteresada, debía también ser la colaboración de los oficiales de las cofradías. Fue directamente el fiscal Alva quien se ocupó de la materia, primero en la cofradía de Calimaya y luego en la de San Homobono de México. La primera contemplaba el pago de un notario para revisar cuentas y asentar las elecciones, y la segunda un pago del $6 \%$ de los caudales recolectados a favor del tesorero de la hermandad, "por el trabajo que ha de impender". El fiscal corrigió: "los nombrados sirvan sin otro interés que el contribuir por su parte al objeto de su instituto" ${ }^{97}$. Otro

89 Dictámenes del fiscal del Consejo. Madrid, 14-I-1798 y 26-IX-1800. AGI, México, 1317.

90 Testimonio del expediente sobre estatutos de la Congregación de Cocheros del Señor Sacramentado de la parroquia de San Pablo, México. 1795. AGI, México, 1309A. ff. 18-21.

91 Dictamen del fiscal del Consejo. Madrid, 3-IX-1802. AGI, México, 2651.

92 Testimonio del expediente instruido en virtud de la real cédula del 19 de noviembre de 1790 sobre la formación de las constituciones de la cofradía de Nuestra Señora de la Merced de la ciudad de Querétaro, México, 1804. AGI, México, 2687. ff. 26-30.

93 El tema de la limosnas de las cofradías ha sido tratado por BAZARTe, 1998 y CARBAJAL, 2010.

94 Dictamen del fiscal del Consejo. Madrid, 6-V-1796. AGI, México, 2649.

95 Dictámenes del fiscal del Consejo. Madrid, 22-II-1797 y 19-VI-1797. AGI, México, 2674 y 2670.

96 Dictamen del fiscal del Consejo. Madrid, 25-VII-1799. AGI, México, 2676.

97 Dictámenes del fiscal del Consejo. Madrid, 3-IX-1802 y 12-V-1803. AGI, México, 2651 y 2683. 
tanto dirá en 1814 el ministro interino que revisó las constituciones de la cofradía de San Ignacio de Loyola, que establecían un pago de 100 pesos anuales a un cuidador de sus utensilios, así como porcentajes del 3\% de pago al tesorero y del $18.6 \%$ a los cobradores. Más tolerante que sus predecesores inmediatos, el letrado concedió que era necesario "algún estímulo que excite la diligencia de los oficiales"98, con lo cual se conformaron los consejeros. No corrieron tan buena suerte las cuotas semejantes establecidas para las cofradías del convento de la Merced de México, la de Nuestra Señora de los Ángeles y de la Purísima Concepción, suprimidas en 1817 y $1818^{99}$. Empero, únicamente la prohibición del pago a los secretarios llegó a quedar incluida en la cédula general de $1805^{100}$.

No hubo en el Consejo, en cambio, manifestación alguna sobre las otras retribuciones que solían recibir los oficiales a través de sus honras fúnebres. En la Audiencia de México era un punto que solía dividir a los letrados que se ocupaban de la reforma. En la cofradía de la Purísima Concepción de Querétaro, por ejemplo, los oficiales debían recibir una misa cantada de cada uno de los frailes franciscanos del convento donde residía la corporación, mientras el resto una sola misa rezada. "Esta distinción, en asunto de igual clase, no considera el fiscal que debe haberla entre los hermanos", afirmó el fiscal Francisco Xavier Borbón. A ello contestaría el asesor general Miguel Bataller que se trataba a la vez de un "premio" para aquellos que "impenden algún trabajo en los negocios de ella", sirviendo además para atraer a todos al ejercicio de los cargos ${ }^{101}$.

En contrapartida, ya que no recibían pago alguno, los oficiales tampoco debían estar obligados a otorgar una fianza formal para resguardo de los bienes que se les entregaban. Aparentemente esta había sido una práctica común en las cofradías novohispanas, especialmente las urbanas, otrora requerida por la autoridad episcopal. Fue el promotor fiscal del arzobispado de México el que impuso fianzas a la cofradía de Ánimas de Tulyahualco en 1716 y a la de Nuestra Señora de los Dolores de Tenancingo en 1723, o tan tarde como en 1788 y 1791, respectivamente, a la sacramental de Chilcuautla y a la de Nuestra Señora de las Mercedes de Querétaro ${ }^{102}$. Para los fiscales de la Audiencia de México la situación no era tan clara: todavía en diciembre de 1795 el fiscal Borbón imponía fianza al mayordomo de la cofradía de la Purísima Concepción de Querétaro, sólo para que fuera rechazada en el dictamen del asesor general Miguel Bataller ${ }^{103}$.

De nueva cuenta fue el fiscal Hernández de Alva quien concretó la reforma, aunque parece ser que la primera iniciativa vino del propio Consejo, que así lo resolvió

98 Dictamen del fiscal del Perú. Madrid, 9-IX-1814. AGI, México, 2699. El dictamen lo elaboró este letrado en ausencia del titular de Nueva España.

99 Dictámenes del fiscal del Consejo, Madrid. 11-VI-1817 y 1-XII-1818. AGI, México, 2700 y 2702.

100 Real cédula dada en San Lorenzo. 15-X-1805. AGI, México, 3096A.

101 Testimonio del expediente promovido por parte del rector, mayordomo y diputados de la cofradía de la Purísima Concepción de Nuestra Señora, fundada desde el año de 1693 en el convento de San Francisco de Querétaro, sobre que se confirme por S.M. dicha cofradía, México. 1796. AGI, México, 1311. ff. 42 v-46.

102 Los expedientes en: AGI, México, 1306, 1311, 2670 y 2687.

103 Testimonio del expediente promovido por parte del rector, mayordomo y diputados de la cofradía de la Purísima Concepción de Nuestra Señora, fundada desde el año de 1693 en el convento de San Francisco de Querétaro, sobre que se confirme por S.M. dicha cofradía, México. 1796. AGI, México, 1311. ff. 42 v-46. 
en el expediente que acabamos de citar, en agosto de $1796^{104}$. Nuevamente el expediente decisivo en la materia fue el de la cofradía de las Benditas Ánimas de Santiago Calimaya, en la cual se suprimía por gravosa y únicamente benéfica a los escribanos públicos que las extendían, pero sobre todo "por no haber [lugar] semejante práctica en las congregaciones piadosas" ${ }^{105}$. La corrección llegó así a la real cédula de 27 de diciembre de 1802, e incluso fue la primera de las indicaciones en la real cédula general de 15 de octubre de $1805^{106}$.

El fiscal Alva cuidó también de que los cargos en las cofradías no fueran un simple acto de vanidad profana. Así se advierte en el expediente de la cofradía del Alumbrado y del Espíritu Santo de Querétaro, cuyas constituciones establecían que los cargos estarían "fincados en las personas de primera distinción", a fin de que fueran un buen ejemplo para el resto de la comunidad. El letrado corrigió: los cofrades debían elegir a los hermanos "más idóneos por su piedad, celo y aptitud", y en ninguna manera por su distinción ${ }^{107}$. Algo semejante en materia de vanidades había hecho ya el fiscal Posada en 1794 al prohibir el uso de uniforme a los militares que integraran la Congregación de Cocheros del Santísimo Sacramento de la parroquia del Sagrario de México ${ }^{108}$, y al cuestionar el uso de "libreas, uniforme, dragonas, competencias por precedencias" en la del mismo instituto de la parroquia de San Pablo en $1796^{109}$. En la misma línea, en 1817 el fiscal del Consejo suprimió el pago del carruaje para llevar a los oficiales al cabildo, dispuesto en las constituciones de la Congregación de Nuestra Señora de los Ángeles de México.

Parte de estas medidas, sin duda, están también relacionadas con otros aspectos de la reforma, como evitar perjuicios al público en el caso de las limosnas, o que sirvieran para aumentar los ingresos de escribanos y notarios eclesiásticos en el caso de las fianzas. Mas de nuevo se trataba de encauzar a las cofradías por el sendero de lo que los fiscales estimaban era una "congregación piadosa". Cabe decir, que esa idea de los fiscales Posada y Alva no era unánimemente compartida en todos sus detalles, entre sus similares de los reinos peninsulares. Si bien la reforma también estaba ligada al tema de purificar la devoción ${ }^{110}$, los esfuerzos en estos puntos concretos parecen haber sido mucho menores, por ejemplo, en el caso de las cofradías de Sevilla. En los poco más de 80 expedientes que hemos podido analizar, los fiscales de la Real Audiencia de Grados de esa ciudad, aunque también trataron constantemente la prohibición de las cuestaciones por las calles, no ponían en cambio obstáculo alguno a la obligatoriedad de las cuotas, ni a la existencia de empleados asalariados de las cofradías (bajo el nombre de muñidores y capilleres), ni a la retribución a los oficiales en sus entierros y funerales. Hubo incluso un caso, el de la hermandad de Santa Justa,

104 Resolución del Consejo. México, 29-VIII-1796. AGI, México, 1311.

105 Dictamen del fiscal del Consejo. México, 3-IX-1802. AGI, México, 2651.

106 Real cédula dada en San Lorenzo. 15-X-1805. AGI, México, 3096A.

107 Dictamen del fiscal del Consejo. Madrid, 30-VI-1803. AGI, México, 2682.

108 Dictamen del fiscal del Consejo. Madrid, 18-I-1794. AGI, México, 2686.

109 Dictamen del fiscal del Consejo. Madrid, 2-II-1796. AGI, México, 1309A.

110 Romero, 1998, pp. 281-300; Rodríguez, 2006, pp. 113-161. 
Santa Rufina y San Millán, en que a un oficial, el mayordomo, le fue impuesta la fianza, no por el fiscal del arzobispado, sino por el de la Audiencia, en $1800^{111}$.

En suma pues, si bien había preocupaciones comunes a todos los tribunales que participaron en la reforma de las cofradías de la Monarquía Hispánica, algunos de ellos podían tener objetivos específicos, en función de sus circunstancias particulares. Es claro que en el Consejo de Indias, bajo las fiscalías de Ramón de Posada y Lorenzo Hernández de Alva sobre todo, se tuvo presente que la piedad de los institutos cofrades no debía mezclarse con intereses profanos, ni con pagos obligatorios, con retribuciones y fianzas, ni con vanidades de las élites. Antes bien, debía brillar en ellas el carácter voluntario, gratuito y sencillo de la devoción.

\section{COMENTARIOS FINALES}

La reforma de las cofradías novohispanas en el Consejo de Indias tuvo pues un primer gran objetivo: hacer de ellas "cuerpos profanos", bajo la jurisdicción de la Corona y no del clero. Empero, no se trataba de convertirlas en "instituciones temporales y no espirituales" "112, sino por el contrario, la reforma tenía también por objetivo reforzar su carácter religioso. En ambos aspectos insistieron sobre todo, en los últimos años del siglo XVIII y primeros del XIX, los fiscales Ramón de Posada y Lorenzo Hernández de Alva, ya desde los tribunales mexicanos, pero en particular en sus años como fiscales del Consejo para Nueva España. De hecho, el fiscal Hernández de Alva podría ser considerado el gran reformador de las cofradías en la región, por su participación en el cierre del expediente general de México, en la revisión de constituciones tanto en México como en Madrid, y en la formación de las reales cédulas de 1802 y 1805.

Aun cuando los impulsores de la reforma tuvieran una amplia lista de recriminaciones hacia los cofradías y algunas de sus prácticas religiosas, ello no parecía implicar que unas y otras debían ser eliminadas, sino más bien purificadas con cierta prudencia ${ }^{113}$. Inclusive en materia de jurisdicción, nunca se atrevieron a desalojar por completo a los párrocos de los cabildos de las cofradías, ni a omitir una primera revisión de sus constituciones por los obispos -algo que sí hizo, en cambio, la reforma peninsular- considerándolos siempre un auxiliar en su vigilancia.

Los fiscales pues, no pretendían desacralizar todas las funciones a las que estaban dedicadas. En cambio, reconocían la importancia sobre todo del culto al Santísimo Sacramento y del sufragio por las Ánimas del Purgatorio. Y debemos insistir sobre ello: no era una mera retórica, los propios letrados hacían parte de la cultura cofrade de la época, y por ello eran tanto más conocedores de sus prácticas. Lo vemos bien en el decisivo dictamen de Hernández de Alva para la cofradía de Ánimas de Calimaya,

111 Expediente formado en virtud de provisión del Consejo para que se informe en solicitud de dichas hermandades sobre aprobación de sus ordenanzas. Sevilla, 1800. AGAS, Justicia, Hermandades y Cofradías, 09801, 16.

112 Bazarte y García, 2001, p. 41.

113 En ese sentido se fue desarrollando la discusión del expediente general, que comenzó con propuestas radicales contra las cofradías, como lo hace notar LuQue, 2003, passim. 
alguna de cuyas reformas se basaban en lo que "ha visto practicar el fiscal en las de que es individuo" 114 .

En ese sentido, los letrados de la Corona intentaban más bien inculcar por esta vía a los fieles del reino de la Nueva España una nueva cultura de la piedad religiosa, que no se limitara a los fastos barrocos sino que incluyera a la caridad y a la utilidad pública como valores, y que comprendiera también una renovada sensibilidad a favor de la protección de lo sagrado y su separación de temas profanos. De alguna forma, los fiscales no hacían sino seguir un camino trazado ya por el propio clero y derivado de la reforma tridentina, compartiendo además con el episcopado, al menos parcialmente, el diagnóstico de los problemas que había que corregir. En todo caso, la novedad era que la Corona reclamara para sí el dictaminar sobre esos límites, los de lo sagrado y lo profano, desplazando en ello, en parte, a la autoridad clerical. Más todavía, se diría que los fiscales se atribuían el deber de proteger la sincera devoción de los fieles expresada en las cofradías, ante las ambiciones profanas de los propios clérigos.

Tales fueron pues, los objetivos de la reforma. Ahora bien, es claro que sus alcances fueron limitados. Llegó a culminarse sólo en un puñado de cofradías respecto del amplio universo de las novohispanas. Sin embargo, algunas de las reales cédulas conteniendo puntos específicos sí lograron tener amplia difusión: la del 8 de marzo de 1791, por ejemplo, que insistía sobre la presidencia de los jueces reales en las juntas cofradías, fue enviada a todos los magistrados de la jurisdicción del virreinato para su puesta en ejecución ${ }^{115}$.

Por otra parte, no es menos destacable la capacidad que tuvieron las cofradías para efectivamente integrar los requerimientos de los fiscales ${ }^{116}$. Las hubo incluso que estuvieron dispuestas a copiar las constituciones de otras ya aprobadas, o a seguir el tenor literal de las reales cédulas (las del 27 de diciembre de 1802 sobre todo), para redactar las propias. Desde luego, escapa a nuestros objetivos comprobar hasta qué punto la reforma fue duradera en las primeras décadas posteriores a la independencia.

En suma pues, el caso de las cofradías novohispanas refleja bien las características de las reformas borbónicas, que sin dejar de impulsar cambios culturales significativos, respetaban en buena medida los marcos corporativos propios de la cultura política de la época. Reforma hecha en los ambiguos límites que lo profano y lo sagrado tenían en el Antiguo Régimen, no dejaba de ser además un esfuerzo original y paradójico de convertir antiguos cuerpos eclesiásticos en cuerpos profanos, para mejor reforzar su carácter piadoso, caritativo y religioso.

114 Dictamen del fiscal del Consejo. Madrid, 3-IX-1802. AGI, México, 2651.

115 Véase el expediente para la ejecución de la cédula en AGN, Cofradías y archicofradías, 18, 1, ff. 1-92.

116 LeMpérIÈre, 2004, pp. 179-180. 


\section{REFERENCIAS BIBLIOGRÁFICAS}

BAZARTE, Alicia

1989 Las cofradías de españoles en la ciudad de México (1582-1860). México. Universidad Autónoma Metropolitana - Azcapotzalco.

1998 "Las limosnas de las cofradías: su administración y destino". En MArTínez LóPez-CANo - von Wobeser - Muñoz Correa (coords.), pp. 65-74.

Bazarte Martínez, Alicia - García Ayluardo, Clara

2001 Los costos de la salvación: las cofradías y la ciudad de México (siglos XVI al XIX). México. Centro de Investigación y Docencia Económica - Instituto Politécnico Nacional - Archivo General de la Nación.

BERNARD, Gildas

1972 Le secrétariat d'État et le Conseil Espagnol des Indes (1700-1808). Ginebra. Librairie Droz.

BRADING, David

1994 Una Iglesia asediada: el obispado de Michoacán, 1749-1810. México. Fondo de Cultura Económica.

Cabantous, Alain

2004 Entre fêtes et clochers. Profane et sacré dans l'Europe moderne, XVII XVIII ${ }^{e}$ siècle. Paris. Fayard.

Callahan, William J.

1998 "Las cofradías y hermandades de España y su papel social y religioso dentro de una sociedad de estamentos". En MARTínez LóPEZ-CANO - VON WoBESER - MuÑoz CORREA (coords.), pp. 35-47.

Carbajal López, David

2010 "Entre la utilidad pública, la beneficencia y el debate: la limosna en Orizaba, 1700-1834". Estudios de Historia Novohispana. México, n43, pp. 109-143.

De la Torre Curiel, José Refugio

2001 Vicarios en entredicho. Crisis y desestructuración de la Provincia Franciscana de Santiago de Xalisco, 1749-1860. Zamora. El Colegio de Michoacán - Universidad de Guadalajara.

DOMPNIER, Bernard (dir.)

2009 Les cérémonies extraordinaires du catholicisme baroque. Clermont-Ferrand, Presses Universitaires Blaise-Pascal.

FARriss, Nancy M.

1995 Clero y Corona en el México colonial. La crisis del privilegio eclesiástico. México. Fondo de Cultura Económica.

García Ayluardo, Clara

1999 "Ceremonia y cofradía: la Ciudad de México durante el siglo XVIII”. En Meyer Cosío (coord.), Identidad y prácticas de los grupos de poder en México, siglos XVII-XIX. Seminario de formación de grupos y clases sociales. México. Instituto Nacional de Antropología e Historia, pp. 67-82. 
2004 "De tesoreros y tesoros. La administración financiera y la pugna en torno a los bienes de las cofradías de la ciudad de México". En MarTínez LóPEZCano - Speckman Guerra - von Wobeser (coords.), pp. 59-83.

2007 "El privilegio de pertenecer: las comunidades de fieles y la crisis de la monarquía católica". En RoJAs (coord.), Cuerpo político y pluralidad de derechos. Los privilegios de las corporaciones novohispanas. México. Instituto de Investigaciones Dr. José María Luis Mora, pp. 85-128.

2010 "Re-formar la Iglesia novohispana". En García Ayluardo (coord.), Las reformas borbónicas, 1750-1808. México. CIDE - FCE - Conaculta - FCE - INEHRM - Fundación Cultural de la Ciudad de México, pp. 225-287.

JARAMILlO MAGAÑA, Juvenal

1996 Hacia una Iglesia beligerante. La gestión episcopal de Fray Antonio de San Miguel en Michoacán (1784-1804) Los proyectos ilustrados y las defensas canónicas. Zamora. El Colegio de Michoacán.

LAVRín, Asunción

1998 "Cofradías novohispanas: economías material y espiritual”. En MarTíneZ LóPez-CANo - von Wobeser - MuÑoz Correa (coords.), pp. 49-64.

LEMPÉRIÈRE, Annick

2004 Entre Dieu et le Roi, La République. Mexico, XVI ${ }^{e}$-XIXe siècles. Paris. Les Belles Lettres.

Luque AlCAide, Elisa

1995 La cofradía de Aránzazu de México (1681-1799). Pamplona. Eunate.

2003 "El debate sobre las cofradías en el México borbónico (1775-1794)". Dieciocho. Hispanic Enlightenment. Charlottesville, vol. 26, nº 1, pp. 25-42.

Martínez López-Cano, María del Pilar - von Wobeser, Gisela - MuÑoz Correa, Juan Guillermo (coords.)

1998 Cofradias, capellanías y obras pías en la América colonial. México. UNAM.

Martínez López-Cano, María del Pilar - Speckman Guerra, Elisa - von Wobeser, Gisela (coords.)

2004 La Iglesia y sus bienes. De la amortización a la nacionalización. México. UNAM.

MAZÍN, Óscar

1987 Entre dos majestades. El obispo y la Iglesia del Gran Michoacán ante las reformas borbónicas, 1758-1772. Zamora. El Colegio de Michoacán.

OlvedA, Jaime

1999 La cofradia de Aranzazú de Guadalajara. Guadalajara. El Colegio de Jalisco - Instituto Cultura Ignacio Dávila Garibi.

Rodríguez Mateos, Joaquín

2006 Las cofradias y las Luces. Ilustración y Reforma en la crisis del Barroco. Sevilla. Ayuntamiento de Sevilla. 
ROMERo SAMPER, Milagrosa

1988 "El expediente general de cofradías del Archivo Histórico Nacional. Regesto Documental". Hispania Sacra. Madrid, nº40, pp. 205-234.

1998 Las cofradias en el Madrid del siglo XVIII. Madrid. Universidad Complutense de Madrid.

TANCK DE Estrada, Dorothy

2004 "Los bienes y la organización de las cofradías en los pueblos de indios del México colonial. Debate entre el Estado y la Iglesia". En Martínez LóPEZCano - Speckman Guerra - von Wobeser (coords.), pp. 33-57.

TAYLOR, William - Chance, John K.

1985 "Cofradías and Cargos: An Historical Perspective of the Mesoamerican Civil-Religious Hierarchy". American Etnologist. vol. 12, nº1, pp. 1-26.

TAYLOR, William

1999 Ministros de lo sagrado. Sacerdotes y feligreses en el México de la segunda mitad del siglo XVIII. Zamora. El Colegio de Michoacán - Secretaría de Gobernación.

ZAHÍNo PEÑAfort, Luisa

1996 Iglesia y sociedad en México, 1765-1800. Tradición, reforma y reacciones. México. Universidad Nacional Autónoma de México - Instituto de Investigaciones Jurídicas. 